\title{
An Adolescent with Hyperimmunoglobulinemia D and Periodic Fever Syndrome Responding to Simvastatin Treatment
}

\author{
Simvastatin Tedavisine Yanıtlı Hiperimmünoglobulin D ve \\ Periyodik Ateş Sendromlu Bir Adölesan
}

\author{
Elif KARAKOÇ-AYDINER, Cevdet ÖZDEMİR, Sevgi KELEŞ, Safa BARIŞ, Nerin N. BAHÇECİLER, Işıl B. BARLAN \\ Departments of Pediatric Allergy and Immunology, Medical Faculty of Marmara University, İstanbul, Turkey
}

The hyperimmunoglobulinemia $D$ and periodic fever syndrome is proposed to be caused by a defect in the activity of mevalonate kinase enzyme which is involved in cholesterol and non-sterol isoprenoid biosynthesis. This autosomal recessive inherited autoinflammatory syndrome is characterized by recurrent fever attacks, abdominal pain, lymphadenopathy, skin lesions and joint involvement. In this article, we present our therapeutic approach with the hypolipidemic agent, simvastatin, in a 12-year-old boy followed up with a diagnosis of hyperimmunoglobulinemia $D$ and periodic fever syndrome. Simvastatin treatment of an adolescent with hyperimmunoglobulinemia $D$ and periodic fever syndrome unresponsive to anti-inflammatory strategies has resulted in a favorable outcome. This treatment is thought to reduce the recurrent fever attacks by reducing the mevalonic acid increase or isopreniod shortage.

Key words: Hyperimmunoglobulinemia D; periodic fever syndrome; simvastatin.

The hyperimmunoglobulinemia-D and periodic fever syndrome (HIDS) is an autosomal, recessive, inherited, autoinflammatory syndrome characterized by recurrent fever attacks, abdominal pain, lymphadenopathy, skin lesions and joint involvement. ${ }^{[1]}$ The responsible mechanism proposed is a mutation in the gene coding for mevalonate kinase $(\mathrm{MVK})$ which results in a deficiency in the
Hiperimmünoglobulin $D$ ve periyodik ateş sendromu kolesterol ve izoprenoid biyo-sentezinde görev alan mevalonat kinaz enzimindeki kusura bağlı olarak ortaya çıkmaktadır. Bu otozomal resesif kalıtımla geçmiş olan oto-inflamatuvar sendrom tekrarlayan ateş atakları, karın ağrısı, lenfadenopati, cilt lezyonları ve eklem tutulumu ile karakterizedir. $\mathrm{Bu}$ yazıda periyodik ateş ve hiperimmünoglobulin D sendromu tanısı ile kliniğimizde izlenmekte olan 12 yaşındaki bir erkek çocuğunda hipolipidemik ajan simvastatin ile uyguladığımız tedavi yaklaşımı sunuldu. Hiperimmünoglobulin $D$ ve periyodik ateş sendromu olan ve diğer antiinflamatuvar tedavilere yanıt vermeyen bir adölesanda simvastatin tedavisi ile klinik düzelme gözlendi. Bu tedavinin mevalonik asit artışını veya izoprenoid azlığını engelleyerek tekrarlayan ateş ataklarını azalttığı düşünüldü.

Anahtar sözcükler: Hiperimmünoglobulin $\mathrm{D}$; periyodik ateş sendromu; simvastatin.

activity of the MVK enzyme enrolling in cholesterol and nonsterol isoprenoid biosynthesis and so called MVK deficiency. ${ }^{[2]}$ Current treatment strategies available for HIDS, however, do not seem to target the underlying pathophysiologic mechanisms of our knowledge. The hypolipidemic agent simvastatin inhibits 3'-Hydroxy-3'-methylglutaryl-coenzyme-A (HMG-CoA) reductase. This can reduce the mevalonic

Received: February 17, 2010 Accepted: May 4, 2010

Correspondence: Cevdet Özdemir, M.D. Marmara Üniversitesi Tıp Fakültesi Pediatrik Allerji ve İmmünoloji Anabilim Dalı, 34662 Altunizade, İstanbul, Turkey. Tel: +90 216 - 3271010 / 788 e-mail: cozdemir@superonline.com

Presented at the XVII. National Allergy and Clinical Immunology Congress, November 3-7, 2009, Antalya, Turkey.

C2011 Turkish League Against Rheumatism. All rights reserved. 
acid overload that may be responsible for recurrent attacks seen in HIDS. ${ }^{[3,4]}$ We describe a 12-yearold boy with HIDS unresponsive to corticosteroid, colchicine and ibuprofen trials since the age of six. The patient responded well to simvastatin treatment. Our findings support the previous reports with the use of this hypolipidemic agent in HIDS.

\section{CASE REPORT}

A 12-years-old boy was admitted with episodes of fever, vomiting, abdominal pain, arthralgia and headache to our unit. In his medical history, the patient reported similar episodes of attacks since the age of six months. It is noteworthy that in between attacks, the patient was in general good health, while physical examination in the febrile phase showed a severely ill patient. He complained about fever $\left(39.2^{\circ} \mathrm{C}\right)$, abdominal pain and headache in his admission which was completely resolved in 4-7 days. His physical examination findings revealed no rash or dysmorphic features. Blood pressure was within normal ranges for age $(110 / 70 \mathrm{mmHg})$. His complete blood count analysis revealed $9100 / \mathrm{mm}^{3}$ white blood cells, $14.8 \mathrm{mg} / \mathrm{dl}$ hemoglobin with a $43 \%$ hematocrit rate and $204000 / \mathrm{mm}^{3}$ platelets. The peripheral blood smear was normal. Erythrocyte sedimentation rate was $64 \mathrm{~mm} / \mathrm{h}$ and C-reactive protein level was $67 \mathrm{mg} / \mathrm{l}$ (normal range $<5 \mathrm{mg} / \mathrm{l}$ ), whereas the fibrinogen level was $5.18 \mathrm{~g} / \mathrm{l}$ (normal range: $2-4 \mathrm{~g} / \mathrm{l}$ ). Serology for various infectious agents and blood culture were negative. The serum immunoglobulin IgD levels were increased in two occasions at least one month apart, as 110 and $198 \mathrm{IU} / \mathrm{ml}$ (normal value: <100 $\mathrm{IU} / \mathrm{ml}$ ), respectively. To address HIDS, analyses of the MVK gene for mutations on exon 9 and 11 were performed and found negative for V377I and I268T. Furthermore, gene analysis was performed for the Mediterranean fever (MEFV) gene on exon 2 and 10 and for the tumor necrosis factor receptor 1A (TNFR1A) gene on exons 2-3, 4-5, and 6-7 including the introns 2,4 and 6 to rule out familial MEFV and tumor necrosis factor receptor-associated periodic syndrome (TRAPS), respectively. No mutations were found. On the other hand, urinalysis showed normal mevalonic acid levels and serum IgA levels. An ultrasonographic examination of the abdomen was normal without any hepatomegaly or splenomegaly. Despite previous trials with several anti-inflammatory drugs including prednisolone, ibuprufen and colchicine, a failure to suppress the episodes of attacks was observed. Regarding the clinical and laboratory data, the patient was diagnosed as HIDS. Thereafter, simvastatin was prescribed at a daily dose of $20 \mathrm{mg}$. During his nine months of follow-up, a marked reduction was observed in the number of attacks (one episode in nine months versus seven in the previous year) with the same daily dose of simvastatin. Furthermore, no side effects were observed with the simvastatin therapy, and acute phase reactants remained negative.

\section{DISCUSSION}

The hyperimmunoglobulinemia-D and periodic fever syndrome is an autosomal recessive disorder generally characterized by 4 to 6 days of lasting inflammatory episodes of fever which tend to recur every 4 to 6 weeks. ${ }^{[5,6]}$ The associated clinical findings of fever episodes may include abdominal distress, vomiting, diarrhea and joint involvement such as arthralgia or arthritis. A physical examination may reveal cervical lymphadenopathy, aphthous ulcers, and a cutaneous rash. ${ }^{[7]}$ Patients with HIDS typically present with persistently elevated levels of polyclonal serum $\operatorname{IgD} .^{[6,7]}$ During febrile episodes, urinary mevalonate concentrations were found to be significantly elevated in patients, but a normal level was reported in an adult-onset HIDS. ${ }^{[8]}$ Our patient had recurrent fever, vomiting and abdominal pain attacks from the age of six months until six years of age. On his admissions, he generally had fever $\left(>39.0^{\circ} \mathrm{C}\right)$, abdominal pain, headache and vomiting in addition to elevated acute phase reactants. He had a markedly high level of polyclonal IgD, but normal urinary mevalonic acid. On the other hand, serum IgA was normal in our case. It has been previously reported that in all but $82 \%$ of cases with typical presentation of HIDS, serum IgA was likewise elevated. ${ }^{[5]}$

The causative mutations in HIDS are located in the gene encoding MVK, an enzyme in the isoprenoid metabolism, the end-products of which include cholesterol, and ubiquinone. ${ }^{[4,9,10]}$ However, it is not always possible to detect the four most prevalently seen mutations (V377I, I268T, H20P/N, P167L) in all patients. $^{[11]}$ Genetic analysis in nearly $30 \%$ of HIDS cases may end with a mutation negative result. ${ }^{[12]}$ Steichen et al. ${ }^{[12]}$ developed a validation criterion, which might be helpful in diagnosing HIDS by only clinical findings. The most discriminatory composite clinical criterion satisfied by all patients with 28 established HIDS was the onset of age less than five-years-old or joint pain during attacks with the length of attacks of 
less than 14 days. ${ }^{[12]}$ Our case was also evaluated for the most common two mutations (V377I, I268T) of the MVK gene and was found negative.

The significance of the elevated IgD levels remains unknown. ${ }^{[1]}$ Research efforts are still ongoing to create a connection between elevated $\operatorname{IgD}$ levels and mutations in the MVK gene. Nagashima et al. ${ }^{[13]}$ suggested a link between the isoprenoid pathway and apoptosis. This showed that inhibition of this pathway by statins induced apoptosis in rheumatoid arthritis synoviocytes.

Several therapeutic approaches have been trialed to control HIDS, including intravenous immunoglobulin, steroids, non-steroidal antiinflammatory drugs, colchicine, TNF- $\alpha$ inhibitors, anakinra and thalidomide..$^{[1,11,14-16]}$ Colchicine and prednisolone had no beneficial effect in preventing the recurrence of attacks in our patient. Recent studies with the HMG-CoA-reductase inhibitor simvastatin have brought hopeful results for the treatment of this disease ${ }^{[3,4,17,18]}$ Simon et al. ${ }^{[4]}$ reported that six patients with HIDS and proven MVK deficiency were followed up for two treatment periods with simvastatin, $80 \mathrm{mg} / \mathrm{day}$, or placebo for 24 weeks separated by a four-week washout period in a double-blind manner Important reductions in the number of attacks and decreased urinary mevalonate were observed. In our case, we have also observed an important reduction in the number of fever attacks.

In conclusion, this data contributes to the hypothesis that simvastatin, an inhibitor of HMG-CoA reductase, has been shown to have a beneficial effect in HIDS by improving auto-inflammatory attack numbers in the HIDS.

\section{Declaration of conflicting interests}

The authors declared no conflicts of interest with respect to the authorship and/or publication of this article.

\section{Funding}

The authors received no financial support for the research and/or authorship of this article.

\section{REFERENCES}

1. Haas D, Hoffmann GF. Mevalonate kinase deficiencies: from mevalonic aciduria to hyperimmunoglobulinemia D syndrome. Orphanet J Rare Dis 2006;1:13.

2. Houten SM, Frenkel J, Waterham HR. Isoprenoid biosynthesis in hereditary periodic fever syndromes and inflammation. Cell Mol Life Sci 2003;60:1118-34.
3. Attout H, Guez S, Ranaivo I, Jameerbaccus N, Series C. A patient with hyper-IgD syndrome responding to simvastatin treatment. Eur J Intern Med 2008;19:e82-3.

4. Simon A, Drewe E, van der Meer JW, Powell RJ, Kelley RI, Stalenhoef AF, et al. Simvastatin treatment for inflammatory attacks of the hyperimmunoglobulinemia $\mathrm{D}$ and periodic fever syndrome. Clin Pharmacol Ther 2004;75:476-83.

5. Drenth JP, Haagsma CJ, van der Meer JW. Hyperimmunoglobulinemia $\mathrm{D}$ and periodic fever syndrome. The clinical spectrum in a series of 50 patients. International Hyper-IgD Study Group. Medicine (Baltimore) 1994;73:133-44.

6. van der Meer JW, Vossen JM, Radl J, van Nieuwkoop JA, Meyer CJ, Lobatto S, et al. Hyperimmunoglobulinaemia D and periodic fever: a new syndrome. Lancet 1984;1:1087-90.

7. van der Hilst JC, Bodar EJ, Barron KS, Frenkel J, Drenth JP, van der Meer JW, et al. Long-term follow-up, clinical features, and quality of life in a series of 103 patients with hyperimmunoglobulinemia D syndrome. Medicine (Baltimore) 2008;87:301-10.

8. Combemale P, Denis-Thely L, Crozes P, Estival JL, Dupin M, Chouvet B. Auto-inflammatory disease with hyperimmunoglobulinemia D of late onset. Ann Dermatol Venereol 2006;133:369-74. [Abstract]

9. Drenth JP, Cuisset L, Grateau G, Vasseur C, van de Velde-Visser SD, de Jong JG, et al. Mutations in the gene encoding mevalonate kinase cause hyper-IgD and periodic fever syndrome. International Hyper-IgD Study Group. Nat Genet 1999;22:178-81.

10. Houten SM, Kuis W, Duran M, de Koning TJ, van Royen-Kerkhof A, Romeijn GJ, et al. Mutations in MVK, encoding mevalonate kinase, cause hyperimmunoglobulinaemia $\mathrm{D}$ and periodic fever syndrome. Nat Genet 1999;22:175-7.

11. Topaloğlu R, Ayaz NA, Waterham HR, Yüce A, Gumruk F, Sanal O. Hyperimmunoglobulinemia $D$ and periodic fever syndrome; treatment with etanercept and follow-up. Clin Rheumatol 2008;27:1317-20.

12. Steichen O, van der Hilst J, Simon A, Cuisset L, Grateau G. A clinical criterion to exclude the hyperimmunoglobulin D syndrome (mild mevalonate kinase deficiency) in patients with recurrent fever. J Rheumatol 2009;36:1677-81.

13. Nagashima T, Okazaki H, Yudoh K, Matsuno H, Minota S. Apoptosis of rheumatoid synovial cells by statins through the blocking of protein geranylgeranylation: a potential therapeutic approach to rheumatoid arthritis. Arthritis Rheum 2006;54:579-86.

14. Demirkaya E, Caglar MK, Waterham HR, Topaloglu R, Ozen S. A patient with hyper-IgD syndrome responding to anti-TNF treatment. Clin Rheumatol 2007;26:1757-9.

15. Drenth JP, Vonk AG, Simon A, Powell R, van der Meer JW. Limited efficacy of thalidomide in the treatment of febrile attacks of the hyper-IgD and periodic fever syndrome: a randomized, double-blind, placebo-controlled trial. J Pharmacol Exp Ther 2001;298:1221-6. 
16. Rigante D, Ansuini V, Bertoni B, Pugliese AL, Avallone L, Federico G, et al. Treatment with anakinra in the hyperimmunoglobulinemia $\mathrm{D} /$ periodic fever syndrome. Rheumatol Int 2006;27:97-100.

17. Houten SM, Schneiders MS, Wanders RJ, Waterham HR. Regulation of isoprenoid/cholesterol biosynthesis in cells from mevalonate kinase-deficient patients. J Biol Chem 2003;278:5736-43.

18. Schneiders MS, Houten SM, Turkenburg M, Wanders RJ, Waterham HR. Manipulation of isoprenoid biosynthesis as a possible therapeutic option in mevalonate kinase deficiency. Arthritis Rheum 2006;54:2306-13. 